\title{
SOUND PRODUCTION IN THE COURTSHIPS OF TWO LYCOSID SPIDERS \\ Schizocosa avida Walckenaer and Tarentula aculeata (Clerck)
}

\author{
by Donald J. Buckle, R.R. I, Preeceville, Saskatchewan
}

In many lycosid species courting males indulge in complex and often spectacular visual displays and a considerable amount of literature has grown up about this. There have been far fewer reports of acoustic displays but whether this is due to the uncommonness of this behaviour or its less conspicuous nature is not presently known. However, the diversity of the species for which acoustic displays have been recorded suggests that such displays are widely distributed throughout the family.

When P. Bonieau in his Discours sur le Langage des Betes (see Bonnet, 1945), published early in the 18th century, me n tion ed "drumming spiders" he may have been referring to a lycosid. More specific information on sound production in this family begins with Lahee's (1904) observations on Lycosa gulosa, the male of which taps its palpi and vibrates its abdomen on the substratum during courtship. This behaviour has since been commented upon by several authors, the latest of whom was Harrison (1969) who included in her paper oscillograms and spectrograms of field-recorded sound. Bristowe and Locket (1926) noted that courting Tarentula pulverulenta males produce sound by vibrating their abdomen on the substratum, and mentioned that "burrowing species of Lycosidae, such as $T$ [rochosa] picta ... drum rapidly with their palps and legs on the ground at the entrance to the female burrow." Chopard (1934) told of finding female Pardosa lugubris, which he assumed to be courting, "dont tout le corps, et les pattes en particulier, sont agités d'un tremblement convulsif, tandis que l'extrémité abdominal frappe rapidement la feuille sur laquelle se trouve l'araignée." In view of Bristowe's
(1929) description of the courtship of $P$. lugubris as a conventional visual one in which the male waves his palpi and legs, it seems probable that Chopard's identification of the species he observed was erroneus. Kaston (1936) mentioned palpal drumming in the courtship behaviour of male Schizocosa crassipes and Lycosa rabida. Rovner (1967) analyzed sound production in the latter species, demonstrating by playback techniques that the sounds played a functional role in the courtship of this species and indicating that the spiders were probably able to perceive airborne sound. He also found that bursts of palpal tapping occurred during agonistic behavior in male-male encounters. Hallander (1967) told of courting male Pardosa chelata producing "a distinct drumming or purring sound" by drumming their palpi on the substratum.

In the course of work in 1969 on the copulatory behaviour of spiders I found that the males of two lycosid species, Schizocosa avida and Tarentula aculeata, produced sounds during courtship. Because of the paucity of literature on the subject, it seemed worthwhile to report on this despite the incompleteness of my data.

Schizocosa avida inhabits dry grasslands and is found throughout the United States and southern Canada. Observations were made in late June on a series of adults collected in southwestern Saskatchewan. Tarentula aculeata is a woodland species found throughout Europe, northern Asia and northern North America. Observations were made during the latter half of May on specimens from east-central Saskatchewan.

All observations were made on captive specimens performing on artificial substrata, usually wood or cardboard. 

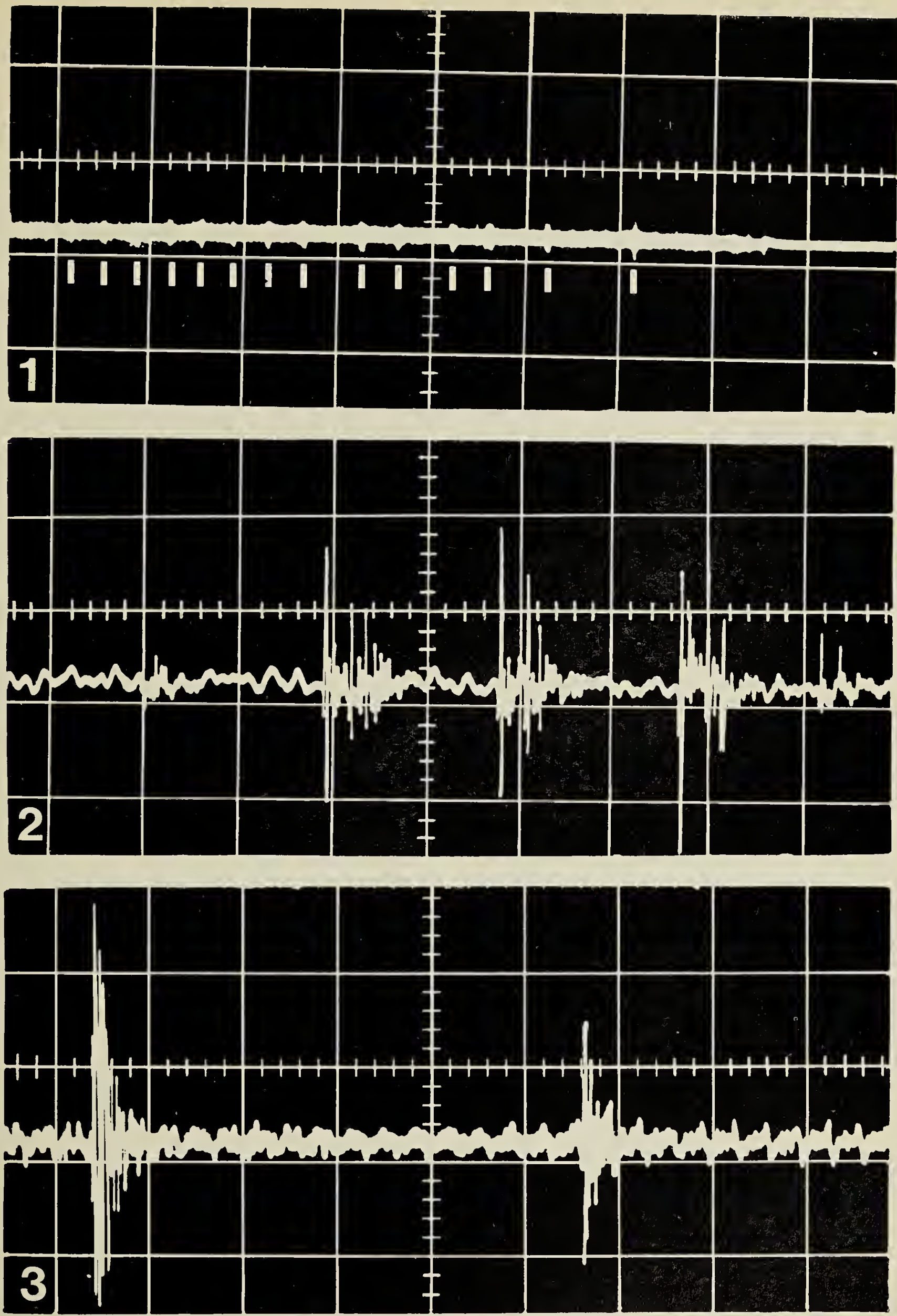

Fig. 1. Schizocosa avida. Sequence of palpal tapping comprised of 14 strums. 1 sec. per square.

Fig. 2. Schizocosa avida. A single strum. 10 sec. per square.

Fig. 3. Tarentula aculeata. Two consecutive impacts of spider's abdomen on substratum. 
For recording purposes a polyethylene container, $16 \mathrm{~cm}$. in diameter, its bottom lined with light cardboard, was uséd as a sound stage. The microphone of a Craig 2107 tape recorder was taped to one side of the container, its head touching the cardboard liner, a position in which it could pick up both air- and substratum-borne vibrations. Single pairs of spiders were placed in the container, and sounds produced during the male's courtship were taped at $3 \frac{1}{2}$ ips, the recorder's maximum speed. The taped sound was later fed directly into a Tektronix 556 oscilloscope and the traces photographed.

The courtship behaviour of Tarentula aculeata was filmed at 24 fps with a Bolex $\mathrm{H} 8$ adapted for the purpose by placing a +3 diopter portra lens over its $8-40 \mathrm{~mm}$ lens. Repeated viewing of the film, including examination of single frames, proved very useful in interpreting the spider's behaviour.

The courting male Schizocosa avida faced the female and rapidly tapped his palpi on the substratum in a sequence of nearly contiguous strums lasting for 2 to 5 seconds and followed by a period of inactivity. Repetitions of this behaviour continued for a half hour or more, the sequences becoming progressively longer and closer together. Shortly before initiating copution the male began to follow his palp tapping sequences by vigorously vibrating his extended first, and occasionally second, pairs of legs on the substratum. Finally, forelegs vibrating, he moved forward, mounted the female and initiated copulation.

Attempts to film palpal tapping of S. avida were unsuccessful so the exact nature of the palpal movements remains unknown. Oscillograms made from recorded sounds showed a series of strums of sound at approximately 0.4 second intervals (Fig. 1). Each strum was $70-80 \mathrm{msec}$. in length and separated by 12 msec. intervals (Fig. 2). The leg vibrations made a swishing sound which was too faint for analysis.
The courting male Tarentula aculeata faced the female and began to vibrate his palpi rapidly back and forth, scraping the substratum with the palpal tarsi. After several seconds of this he rushed forward, his front legs elevated, repeatedly raising and dropping his body as he went. Just before contacting the female he veered to one side and halted. After a short pause the sequence was repeated. Repetitions continued for several minutes. If the female was receptive and sat quietly the male finally mounted her, rather than turning aside at the end of one of his rushes, and initiated copulation.

The palpal vibrations of $T$. aculeata produced a scratching sound which pulsated slightly and irregularly in volume. Unfortunately, recordings of the sound were not of sufficient quality to produce satisfactory oscillograms. Examination of the film showed that the tarsal tip of each palp was scraped back and forth on the substratum about seven times per second. The palpal movements were usually, but not always, in alternation. Each time the male dropped his body during a forward rush his abdomen struck the substratum with a sharp "plop" that was louder than the palpal scraping. During a rush, which might last for one and a half or two seconds, his body was raised and dropped three or four times per second (Fig. 3).

Because experimental evidence is lacking, it is difficult to say whether or not the sounds produced by $S$. avida and $T$. aculeata serve any communicatory function. But since palpal tapping is the principal component in the courtship of $S$. avida, it seems likely that the sound is functional. The situation is less clear with the palpal scraping of $T$. aculeata, as the courtship of this species also includes visual display. The sounds produced by the anterior legs of S. avida and the abdomen of $T$. aculeata may well be non-functional by-products of behaviour directed toward tactile and visual stimulation, respectively. Ex- 
perimental studies are needed to determine the roles of these various movements and sounds during precopulatory behaviour in these species.

\section{Acknowledgments}

Thanks are due to D. W. Whitfield and R. C. Holmberg who produced the oscillograms and to Dr. J. S. Rovner for his helpful comments.

\section{LITERATURE CITED}

Bonnet, P. 1945. Bibliographia Araneorum. Tome I. Les Frères Douladoure. p. 274.
Bristowe, W. S. 1929. The mating habits of spiders, with special reference to the problems surrounding sexual dimorphism. Proc. Zool. Soc. Lond., 309-358.

Chopard, L. 1934. Sur les bruits parduits par certaines araignées. Bull. Zool. Soc. Fr., $59: 132-134$.

Hallander, H. 1967. Courtship display and habitat selection in the wolf spider Pardosa chelata (O. F. Muller). Oikos, $18: 145-150$.

Harrison, J. B. 1969. Acoustic behavior of a wolf spider, Lycosa gulosa. Anim. Behav., $17: 14-16$.

Lahee, F. H. 1904. The calls of spiders. Psyche, $11: 74$.

Rovner, J. S. 1967. Acoustic communication in a lycosid spider (Lycosa rabida Walckenaer). Anim. Behav., $15: 273-281$.

\title{
THE BUTTERFLIES OF MANITOBA'S PROVINCIAL PARKS I: WHITESHELL PROVINCIAL PARK
}

\author{
by John H. Masters, P.O. Box 7511, St. Paul, Minnesota
}

With 675,840 acres, Whiteshell is Manitoba's largest provincial park. Located in extreme southeastern Manitoba, it can be reached by the TransCanada highway No. 1 or Manitoba trunk highway No. 4. The region is typical boreal zone of eastern Manitoba and northern Ontario. It is situated on Precambrian or Canadian Shield where lakes, rivers, acid bogs and rock outcroppings are all numerous. Birch and aspen forests cover most of the region, but these are replaced by jack pine on rock outcroppings or sandy areas, by black spruce in bogs, and by larch in swampy areas.

The butterflies of Whiteshell have received some attention in the past. George Shirley Brooks, who published a check-list of the butterflies of Manitoba (1942), collected at Seven Sisters Falls before the Provincial Park was formed, and recorded several species from here. Charles D. Bird spent the summers of 1954 and 1955 at Red Rock Lake and published a list (1956) of 40 species of butterflies he collected there. Between 1966 and 1971, I made six collecting trips to Whiteshell as part of field work on a Manitoba Lepidoptera project. My collecting has added several species to Bird's list and in addition, I am adding adult flight date and habitat data that were missing from the previous reports. Skippers (Hesperiidae) have not been included in this study.

\section{Species List \\ Swallowtail Butterflies: \\ PAPILIONIDAE}

TIGER SWALLOWTAIL Papilio glaucus canadensis Rothschild \& Jordan A common and conspicuous species of roadsides and deciduous forests. Adults in mid-June to early July.

\section{Whites and Sulphurs:}

\section{PIERIDAE}

NORTHERN WHITE Pieris napi oleracea Harris One of very few double-brooded species in this region. 'The first brood emerges in mid-May and may be taken until mid-June, the second brood is on the wing in August. A woodland species.

CABBAGE BUTTERFLY Pieris rapae (Linnaeus) This is an ubiquitous species originating from Europe and reported from Whiteshell by Bird. The butterflies would not be expected to penetrate any of the forested areas and are more to be expected around gardens or human habitats. They would be expected to fly throughout the summer period.

ORANGE SULPHUR Colias eurytheme eurytheme Boisduval $\mathrm{T}$ h is species is not especially common at Whiteshell. It is to be found in late 